\title{
Development of Learning Media Based on Problem based Learning in Prakarya
}

\author{
Ahmad Dahlan Siregar \\ Educational Technology, Postgraduate \\ Universitas Negeri Medan \\ Medan, Indonesia \\ ahmaddahlan26@gmail.com
}

\author{
Mukhtar \\ Educational Technology \\ Universitas Negeri Medan \\ Medan, Indonesia
}

\begin{abstract}
This study aims to: produce appropriate Compact Disc (CD) learning products according to material experts, media experts, design experts and users and find out the usefulness of products through the completeness of student learning outcomes. This research is development research conducted in two strages. In the analysis and design phase, a survey was conducted in the field to analyze student needs. The design stage is tailored to the needs of learning activities. The results of this study are as follows. Learning CD are declared feasible and Effectiveness proven by improvement student learning outcomes, Student responses generally respond positively.
\end{abstract}

Keywords: Compact Disc, problem based learning

\section{INTRODUCTION}

In Law Number 20 Year 2003 concerning the National Education System in Article 3 stipulates that national education functions to develop capabilities and shape the dignified character and civilization of the nation in the context of educating the life of the nation and aiming at developing the potential of students to become people of faith and piety to God Almighty, noble, healthy, knowledgeable, capable, creative, independent, and become citizens who are democratic and responsible[1].

Changes in curriculum from KTSP to 2013 Curriculum adapted to the development of national life, the demands and needs of the community; science, technology, art, skills and other fields, and national education policy. With the changing community needs it needs to be anticipated and implemented into the education curriculum. This condition makes the government carry out evaluations and improvements to keep it in accordance with the demands and needs of the community.

In applying the 2013 curriculum, the role of information and communication technology is very important. At this time we can see that information and communication technology is developing very rapidly and has a huge influence on changing

the learning process. Information technology plays an important role, especially in providing innovation in learning. Students are expected to be able to utilize information technology in the learning process independently.

The learning development process is certainly different for each lesson, adapted to the nature or concept of the subject. The more abstract the concept of a lesson, the more difficult it is to teach the concept to students. The concept requires visualization to facilitate understanding of students. One of them is there are a lot of material concepts that require visualization to be easily understood by students.

In the observation of researchers found the low quality of the learning process and learning outcomes of craft learning, this is not in line with expectations where student achievement is still low seen from student learning outcomes are low and students are still less interested in participating in learning crafts.

Then in terms of instructional media, in most craft lessons the teacher has not used it optimally. Educators in conducting more learning are still conventional in nature, using student books and worksheets so that students feel bored and educators still dominate the course of learning and have not utilized the multimedia-based learning resources optimally so that learning tends to be less attractive to students. This is thought to be one of the causes of the low quality and learning outcomes of craft subjects. Efforts to improve student learning outcomes are inseparable from various factors that influence it. In this case the teacher's creativity is needed that can make learning media interesting and liked by students.

From preliminary observations made by researchers, multimedia support facilities are available school environment, but this facility is not utilized by subject teachers due to the lack of teacher knowledge in using these facilities, resulting in a lack of creative power in the learning process. From the questionnaire given to 36 students taken as samples, $85 \%$ of students stated that they needed interactive learning media that could be used as learning media independently.

The learning process requires an interesting and fun learning media as a source of independent learning for students. Through interesting learning media, psychologically students will become interested and eager to learn both in the classroom and outside the classroom. One effort to develop an interesting and enjoyable learning process is through multimedia-based learning as a source of student learning.

Development of learning media can answer and solve problems and difficulties of students in learning. Mastery of a competency in learning is very important, for that students need the right model or model. With the development of 
appropriate learning multimedia, these difficulties can be overcome, this cannot be separated from the role of learning technology, namely theory and practice in the design, development, utilization, management and evaluation of processes and resources for learning. So, research on developing multimedia learning is included in one area of learning technology, namely in the area of development (Development).

Learning technology applies the principles of science in solving learning problems, this view assumes that science and technology cannot be separated, the results of the study show that using learning media in the form of learning videos makes learning more effective and a lot of fun. Effective teaching materials are needed so that the learning process is not monotonous and does not make students bored due to inappropriate material.

In an effort to improve learning outcomes on healthy fast food processing materials from fruits and vegetables. In the delivery of healthy fast food processing materials from fruits and vegetables with PBL (Project Based Learning) learning model. PBL is broadly a learning model that uses projects / activities as a medium. Learners explore, evaluate, interpret, synthesize, and information to produce various forms of learning outcomes. Teaching material using PBL is expected to be effective in the learning of students in the classroom in producing healthy fast food processing works from fruits and vegetables.

Based on the description above, researchers conducted research using teaching material as a source of student learning that is used to improve thinking skills by enriching real problems in daily life, especially problems in the school environment so that it is expected to improve student learning outcomes in fast food processing materials healthy serving of fruits and vegetables.

\section{RESEARCH METHODS}

This research is a research and development strategy to be able to develop an educational product. The development that has been carried out is Problem Based Learning based learning media on craft subjects. To produce a learning media product, Bold and Gold development steps are used. In learning instructional development, Dick \& Carey's learning development model is used. The procedure of developing problem based learning (PBL) based learning media on craft subjects is related to the preparation of learning tools in the form of learning media needed to organize learning. The learning media developed were analyzed using the validation of the material expert team, the design of instructional media and the assessment of teachers and students using rubrics developed by Sriadhi [2]. The development procedure in this study is shown schematically in Figure 1.

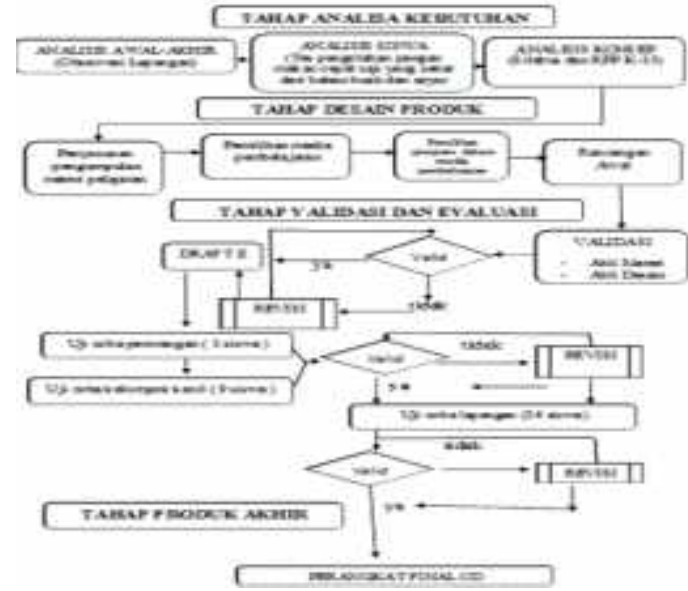

Fig. 1. Procedure for Developing Combined Learning Media Borg \& Gall Models

\section{Requirement Analysis Phase}

a. Front-end analysis

Front end analysis aims to bring up and determine the basic problems faced in learning, so we need a development of learning media. This analysis is carried out observations in the field through interviews with field study teachers about the learning media used.

\section{b. Learner analysis}

Student analysis is a study of the characteristics of students in accordance with the design of the development of learning devices. These characteristics include the background of academic ability (knowledge), cognitive development, as well as individual or social skills related to the chosen learning topic, media, format, and language. Student analysis is done to get a picture of the characteristics of students, including: (1) the level of ability or intellectual development, (2) individual or social skills that are already owned and can be developed to achieve the specified learning goals.

\section{c. Concept Analysis}

Concept analysis is carried out to identify the main concepts to be taught, arrange them in a hierarchical form, and break down individual concepts into critical and irrelevant matters. This analysis was carried out by preparing syllabus and lesson plans based on the 2013 curriculum used.

\section{d. Task Analysis}

Task analysis aims to identify the main skills that will be studied by researchers and analyze them into a set of additional skills that may be needed. This analysis ensures a thorough review of the assignments in the learning material.

\section{e. Specifying instructional objectives}

The formulation of learning objectives is useful for summarizing the results of concept analysis and task analysis to determine the behavior of the research object. The collection of objects becomes the basis for compiling tests and 
designing learning tools which are then integrated into the learning device material that will be used by researchers.

\section{Product Design Stage}

a. Constructing criterion-referenced test

The preparation of the benchmark reference test is a step that connects the definition stage with the design stage. Benchmark reference tests are based on student learning objectives and analysis specifications.

b. Media selection

Media selection is carried out to identify learning media that are relevant to the characteristics of the material. The selected media in the form of learning media in the form of Video Compact Disc.

c. Format selection

The choice of format in the development of learning tools is intended to design or design learning, selection of strategies, approaches, learning methods, and learning resources. The format chosen is one that meets the criteria of attracting, facilitating and assisting in learning crafts. The format chosen in the development of instructional media is to use Problem Based Learning.

d.Initial design

The initial design in question is the design of all learning tools that must be done before the trial is carried out. It also includes a variety of structured learning activities such as reading texts, interviews, and the practice of different learning abilities through teaching practice.

\section{Validation and Evaluation Stage}

a. Expert appraisal

The assessment of experts / practitioners on learning tools includes: programs, languages, illustrations, and content. Based on input from experts, learning materials are revised to make it more precise, effective, easy to use, and have high technical quality. Learning media development products require feedback in the context of evaluation, the feedback obtained from research subjects consisting of learning design experts, media experts, material experts, and product users, namely VII grade students of SMP Negeri 35 Medan.

b. Developmental testing

Field trials are conducted to obtain direct input in the form of responses, reactions, student comments, and observers to the learning tools that have been compiled, trials, revisions, and retries continue to be carried out until a consistent and effective device is obtained.

\section{Trial design}

The trial design stages are as follows:

a) Expert validation of the craft material

b) Validation of media experts

c) Validation of instructional design experts

d) Conceptual analysis

e) Revised phase I development, based on an assessment in the form of input, criticism and suggestions from 2 material experts, 2 medai experts, 2 instructional design experts for improvement.

f) Individual trials g) Conceptual analysis

h) Revised phase II development, based on assessments in the form of input, criticism and suggestions from 3 VII grade students who have low, medium and high achievements. i) Small group testing, assessment of the product based on a questionnaire that was filled out by 9 students of grade VII

j) Conceptual and product analysis.

k) Phase III revision

1) Field trials on 32 Grade VII students

m) An assessment of the attractiveness and feasibility of the product

n)Empirical analysis (stage IV)

o)Minor revisions and tests of product effectiveness

p) Final product

\section{Final Product Stage}

The dissemination process is a final stage of development. Dissemination phase is carried out to promote development products to be accepted by users, both individuals, a group, or the system.

\section{RESULTS AND DISCUSSION}

This research and development aims to produce a product in the form of problem-based learning media based on craft subjects for class VII. The development of this instructional media product is carried out with reference to the research and development model [3] and is integrated with the instructional design model from Dick and Carey. Research and development of instructional media has been carried out procedurally according to the stages of research development and instructional design of the two models. The stages that have been carried out in the research and development of this learning product are:

First, the preliminary stage by conducting needs analysis through initial observation, interviews and literature study. From the results of this needs analysis, general learning objectives (competency standards) can be formulated. Then conduct an analysis of learning so as to identify the ability requirements that students must have to achieve the general learning objectives. Next identify the characteristics of students, formulate basic competencies and learning indicators, prepare a benchmark reference test or evaluation to assess whether students have been able to achieve learning objectives or not. After that the learning strategies are stated in the syllabus and lesson plans. The next step is to develop learning material that will be published in this problem based learning media. This preliminary stage is in accordance with the instructional design stage of[4].

Second, the planning stage by containing the problembased learning media design scheme developed. Then make a script, storyboard, collect / make learning materials, pictures, audio and video.

Third, the stage of developing the content of learning media based on problem based learning which includes opening, main menu, usage guidelines, competencies, learning objectives, material map, description of learning, relevance of learning, description of material and exercises, summary, 
evaluation, feedback, glossary and closing. The second and third stages are in accordance with the research and development model of Borg and Gall.

Fourth, the validation stage by 2 experts in learning materials, 2 experts in learning design, 2 experts in media. The learning media developed were revised according to the input of the experts.

Fifth, the stage of the trial consisting of individual trials (3 students), small group trials (9 students), field trials (32 students). The fourth and fifth stages are in accordance with the instructional design procedures by Dick and Carey at the formative evaluation stage and so are the research and development procedures by Borg and Gall at the product testing and revision stage.

This product development research conducted is directed to produce a product in the form of problem-based learning media that is developed which is used to improve quality and learning outcomes.

Benefits in the use of instructional media in craft subjects are as follows the material is easy to understand because the concepts presented are planned to facilitate students and systematically, learning media in subjects based on problembased learning gives opportunities for students to learn according to the speed of each individual,learning faster and more interesting so as not to cause boredom because it is equipped with animated images and practice questions, this learning media can also be used as an alternative learning media individually.

\section{Discussion of Product Feasibility Test Results}

Based on the results of the validation conducted, the learning media product was declared eligible to be continued in the field trials. The learning media developed have met the standards based on the design standards for the development of learning materials, learning designs and instructional media and are in accordance with the characteristics of students as users and have met the learning needs of students.

The results of the questionnaire submitted to media experts gave an average percentage of response scores of $91.69 \%$ that the development of learning media based on problem based learning developed in learning was appropriate for use because it had fulfilled the principles and criteria for developing interactive learning media. Meanwhile, learning design experts give an average percentage of response scores of $90.24 \%$ that the development of learning media based on problem based learning that is developed is feasible to use because it has been designed in such a way and meets the learning design standards. Learning material experts gave an average percentage of response scores of $91.83 \%$ that the development of learning media based on problem based learning that was developed was appropriate because it contained material and delivery criteria that met the requirements for delivering messages to students.

By looking at the guidelines and evaluation criteria according to [5] and in line with what was revealed by [6] that the media contained information and knowledge that was deliberately designed to make students facilitated to communicate and learn. it can be concluded that the data above proves that the use of problem based learning based learning media is very feasible to be used by students on craft subjects.

\section{Discussion of Research Results of Product Effectiveness Test}

The effectiveness test of the problem-based learning media product that has been developed is carried out to fulfill the instructional design procedures of Dick and Carey at the summative evaluation stage. The purpose of this product effectiveness test is to determine whether the product needs to be used continuously because it is effective or is stopped because it is ineffective. The effectiveness test of the developed learning media product has been carried out by comparing the average value of the learning outcomes of the craft learned with the media with the average value of the learning outcomes learned by not using media. From the results of data processing research conducted, there are differences in the results of craft learning between students who are taught using problem based learning media and students who are taught without problem based learning media.

The effectiveness of problem based learning based learning media is caused by the creation of an independent learning system. The developed learning media is able to meet all the principles of media development that can be used in learning as expressed by[7]. In line with the principle of selecting learning material provided which includes the principles of relevance, consistency and adequacy.

The effectiveness of learning media based on problem based learning proves the statement of [8] which distinguishes three groups of learning media in improving learning outcomes, namely (1) learning multimedia that is able to simplify complex material to be simple, visualize conceptual events to be concrete, help to be able to improve results study. (2) multimedia learning is able to overcome the weaknesses of students' cognitive abilities. Learning media can visualize teaching materials that will reduce cognitive burdens so that it is easy to accept teaching materials that will ultimately improve learning outcomes. (3) multi-media learning presents teaching materials in the form of text, graphics, visuals, videos and animations capable of arousing student learning motivation so as to improve learning outcomes.

Thus the problem based learning media that have been produced are effective for use in learning. The ability of teachers to act as motivators and elevators also greatly influences student learning outcomes because in media-based learning problem-based learning students must be motivated to be fully responsible for their learning tasks. As an elevator, the teacher must always be consistent to provide feedback at the right time.

\section{CONCLUSION}

Based on the results of the analysis and discussion in this study, it can be concluded as follows : 
1. Problem-based learning media products that are developed in craft learning have met the requirements and are suitable for use as learning media. This was concluded based on the results of the assessment experts which overall stated that problem based learning based learning videos were in the "very good" category.

2. The use of learning media based on problem based learning developed is considered more effective in improving student learning outcomes. this is concluded based on student learning outcomes that are taught with video media based on problem based learning higher than learning outcomes without using video learning media based on problem based learning.

\section{ACKNOWLEDGMENT}

In this occasion the author expressed his appreciation and profound gratitude to SMP Negeri 35 Medan who have supported the author in terms of morale and meteril. The author also expressed my deepest gratitude to all parties who have helped until this paper can be completed.

\section{REFERENCES}

[1] Anonim. 2003. Undang-undang Republik Indonesia Nomor 20 Tahun 2003 Tentang Pendidikan Nasional. Jakarta: Departemen Pendidikan Nasional.

[2] Sriadhi, 2018. Penilaian Kelayakan Multimedia Pembelajaran.MedanUniversitas Negeri Medan.

[3] Borg and Gall. 1983. Educational Research, An Introduction. New York and London. Longman.Inc

[4] W.Dick and L.Carey. 2005. The Sistematic Desain Of Instruktional. Allyn And Bacon, Boston

[5] Sugiyono. 2013. Metode Penelitian Pendidikan Pendekatan Kuantitatif, Kualitatif, $\quad$ dan $R \& D$. Bandung: Alfabeta

[6] Sugiyono. 2016. Metode Penelitian dan Pengembangan Researc and Development $/ R \& D$. Bandung: Alfabeta

[7] S.E.Smaldino,Deborah L.Lowther, James D.Russell. 2014 Instructional Technologi and Media For Learning. Jakarta : Kencana

[8] Sriadhi, 2015. Analisa karakteristik media pembelajaran dan motivasi berdasarkan gaya belajar siswa sekolah menengah kejuruan. Jurnal Manajemen Pendidikan PPs Unimed Educandum, Volume VIII, Nomor 2, Desember 2015, hal 37-47. 